\title{
THEORETICAL STUDY OF THE STRUCTURAL AND ENERGETICS PROPERTIES OF THE INTERACTION SIDES OF GUANINE AND ADENINE IN GG AND AA TRANS BASE PAIRS
}

\author{
SANDRA T. MADARIAGA ${ }^{* 1}$, J. GUILLERMO CONTRERAS $\digamma^{2}$ \\ ${ }^{I}$ Centro de Docencia Superior en Ciencias Básicas, Universidad Austral de Chile. Sede Puerto Montt. \\ Casilla 1327, Puerto Montt, Chile \\ ${ }^{2}$ Facultad de Ciencias Químicas. Universidad de Concepción. \\ Casilla 160, Concepción, Chile \\ (Received: June 8, 2012 - Accepted: August 17, 2012)
}

\begin{abstract}
In the present work we have carried out an ab initio study on the structural and energetic properties of the hydrogen bonding formed between the different interaction sides of Guanine $(\mathrm{G})$ and Adenine (A) in the GG and AA trans non Watson-Crick base pairs. The energies derived at the HF/6-31G(d,p) level, show that while Watson-Crick sides contribute significantly to the stabilization of the hydrogen bonding, however, Sugar and Hoogsteen sides interacciones are weaker. The inclusion of electronic correlation at the second order Møller- Plesset perturbation method, confirm the importance of including this correlation at MP2/6-31G(d,p) and MP2/6-311G(d,p) levels. It is concluded that two Guanine molecules form hydrogen bonds energetically more favorable than AA pairs within the same kind of interaction, while those having the sugar-sugar GG interaction become better solvated in aqueous solution. The results also allow understanding the functional role of this type of interaction in the oligonucleotide.
\end{abstract}

Keywords: ab-initio, non-Watson-Crick base pairs, interaction energies.

\section{INTRODUCTION}

The DNA and RNA nitrogen bases have received permanent interest due to their role in molecular recognition processes of biological importance $e^{1-7}$. In these processes, mainly characterized by non-covalent interactions, it can be observed $^{7-10}$ that all sides of the nucleobases (Fig. 1) are able to form hydrogen bonds allowing the recognition of different ligand, such us proteins, nucleic acids, drugs and metals. However, the Watson-Crick sides (WC) occur more frequently. In the RNA-proteins interactions ${ }^{10}, 72 \%$ of these interactions involve the WC sides, $35 \%$ involve the Hoogsteen sides $(\mathrm{H})$ of the nucleobases and the sugar sides $(\mathrm{S})$ only occur in a $0.01 \%$. In the RNA-nucleobases interactions, the Sugar sides occur in a $27 \%$, a similar percentage (33\%) occurs when the Hoogsteen sides participate in this kind of interaction ${ }^{11}$.

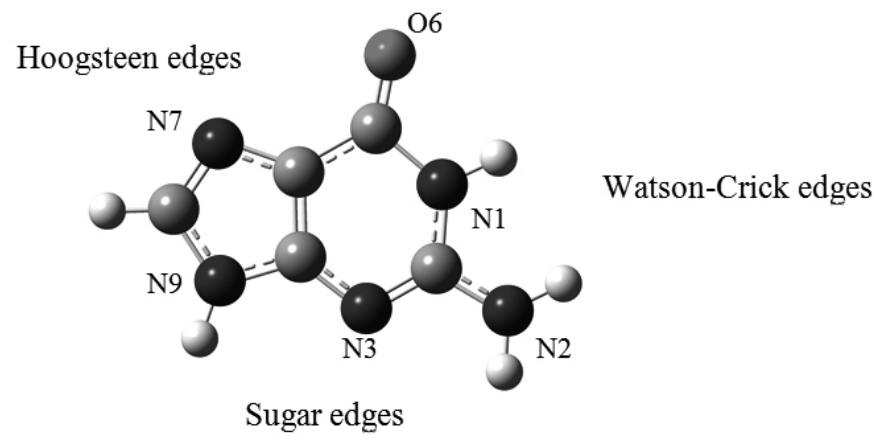

Fig. 1: Edges interaction in Guanine.

Although the WC/WC interactions between complementary nucleobases (GC, AU and AT) define the secondary nucleic acids structures, they are essentials to preserve the genetic $\operatorname{code}^{12}$ and provide stability to the three dimensional structure of these oligonucleotides ${ }^{13}$. Other models of interactions also play important functional and structural roles and are relevant in genetic expression and cell stability ${ }^{6,14}$. In fact the differences in the thermodynamic stability of certain RNAs and their associated functions cannot be explained only for the presence of hydrogen bonds observed in GG and AU pairs ${ }^{15}$. In the molecular recognition processes, the electron donor and acceptor groups of the Hoogsteen and Sugar sides have a particular interest. In RNA-protein complexes it is observed that whereas the N7 and O6 atoms of Adenine recognize various types of aminoacids, Guanine only recognizes Arginine ${ }^{10}$. This preference recognition is also seen in some drug antineoplasics insertion processes, like cis-platin and derivatives that show a higher affinity for N7 of Guanine over N7 of Adenine ${ }^{3}$. This is particularly interesting since it is observed $70 \%$ of GG sites and $20 \%$ of GA sites 3 in the DNA cancer cells. RMN studies and molecular dynamic simulation suggest that the Pt-GG DNA adduct modifies the structural properties of mutated DNA allowing the incorporation of the mismatch repair protein ${ }^{16}$. In $\mathrm{Cu}(\mathrm{II})$-nucleobases interactions ${ }^{17}$, Adenine uses N3 atom to coordinate the divalent metal ion while Guanine uses N7 atom, evidencing the capability of the latter one to form metal-Guanine clusters in a similar configuration as the Guanine quartets observed in $\mathrm{DNA}^{8,18-19}$, where interactions $\mathrm{WC} / \mathrm{H}$ with cis glycosidic bond characterize the formation of hydrogen bonds amongst the purines, involving 4 molecules of Guanine. No quartet formed by GG with trans glycosidic bond, have been detected so far, as well as among either other DNA or RNA nitrogen bases. In RNA, WC/ WC interactions in GG and GA pairs modify the RNA deep groove allowing the protein insertion and then its recognition ${ }^{2,20}$. Although GG pair does not participate directly in that kind of recognition, it has been suggested that N7 and O6 atoms of the GG and GA pairs form polar hydrogen bonds with aminoglycoside antibiotics ${ }^{2,20-22}$. These drugs are also inserted in DNA triplex structure ${ }^{23,24}$, where N7 and $\mathrm{O} 6$ atoms are found available in the purine bases of the third strand oligonucleotide ${ }^{25}$. In these complex structures, most likely associated with DNA repairing processes, it also observed that the Hoogsteen sides of the DNA nitrogen bases form hydrogen bonds with the WC sides of the third strand of DNA, forming the GG and AA pairs ${ }^{23,24}$. The orientation of glycosidic bonds in the different non canonical base pairs also plays an important role in relation to the structure and function of the nucleic acids, where the cis interactions show a negative propeller unlike trans pairs where no preference is observed and it conformational flexibility is reduced by the triple base formation ${ }^{26,27}$. In fact, it is seen ${ }^{26}$ that the propeller of the two molecules of Guanine in the trans $\mathrm{S} / \mathrm{S}$ GG pair decreases ca. $18^{\circ}$ after the interaction with $\mathrm{GC}$ pair, while the latter varies ca. $8.0^{\circ}$ to $12.3^{\circ}$. The higher frequency of the triple bases in the RNA is formed by trans WC/WC AA and S/S GG base pairs.

This paper focuses on the calculation of the stabilization energies, especially on the Watson-Crick/Watson-Crick, Watson-Crick/Hoogsteen and Sugar/Sugar interactions in GG and AA base pairs, their structural properties and their associated geometries. The study of the properties of the interaction edges of the DNA and RNA nitrogen bases, contributes to understand the properties that govern the processes of molecular recognition.

\section{COMPUTATIONAL METHODS}

Standard ab-initio calculations, in the frame of molecular orbital theory, were performed using GAUSSIAN $09 \mathrm{~W}$ suite of programs ${ }^{28}$. Geometry optimization of each pairs were carried out at $\mathrm{HF} / 6-31 \mathrm{G}(\mathrm{d}, \mathrm{p})$ level, followed of frequency calculations in order to see whether the derivate structures were local minima. Energy calculations in gas phase at MP2/6-31G(d,p) and MP2/6-311G(d,p) levels were carried out to include electron correlation in the frozen core approximation. The interaction energies were obtained from 
E value for the pair to which the energies of the isolated guanine have been subtracted. BSSE (Basis Set Superposition Error) corrections were calculated using the counterpoise methods (CPM) formulated by Boys and Bernardy ${ }^{29}$. Accordingly, BSSE $(\mathrm{XY})=\mathrm{E}(\mathrm{X}) \mathrm{x}+\mathrm{E}(\mathrm{Y}) \mathrm{y}+\mathrm{E}(\mathrm{X}) \mathrm{xy}-(\mathrm{E}(\mathrm{Y}) \mathrm{xy}$, were $\mathrm{E}(\mathrm{X}) \mathrm{xy}$ is the energy of $X$ calculated at the super molecule basis set, $E(X) x$ corresponds to the energy of $X$ calculated at its own basis set. It is known that CPM works well at HF level, whereas conflictive opinions have been reported on the applications to correlated methods ${ }^{30,31}$, and thereby in this work were used to confirm the magnitude of the stabilization of each pair only. The solute-solvent interactions were modeled using the polarized continuum method $(\mathrm{PCM})^{32,33}$. Accordingly, our calculations account for the polarization contributions and non-electrostatic terms such as cavitations, dispersion and repulsion energies.

\section{RESULTS AND DISCUSSION}

The optimized structure of the interactions between the nucleobases is shown in figure 2, where I, II and III correspond to the interactions WC/ $\mathrm{WC}, \mathrm{WC} / \mathrm{H}$ and $\mathrm{S} / \mathrm{S}$ respectively. In all cases, it was used a tautomeric form energetically more stable of purine bases; i.e. $\mathrm{N} 9-\mathrm{H}^{34}$. In the same way, it has been found previously, in purine and azapurine pairing ${ }^{35-37}$, the geometric parameters of those atoms not involved in the hydrogen bonds are not affected significatively after the hydrogen bonding formation. The hydrogen bonds between the nucleobases are polar $\left(\mathrm{N}-\mathrm{H}^{\cdots} \cdot \mathrm{N}\right.$ and/or $\left.\mathrm{N}-\mathrm{H} \cdots \mathrm{O}\right)$, presenting bond distances close to $2.0 \AA$ and bond angles in the range of 164-175 degrees (Table 1), the non-bonded distances $\mathrm{N} \cdots \mathrm{N}$ y N $\cdots \mathrm{O}$ are ca. $3.0 \AA$, similar to those found in GC, AU and AT base pairs ${ }^{35-36}$.
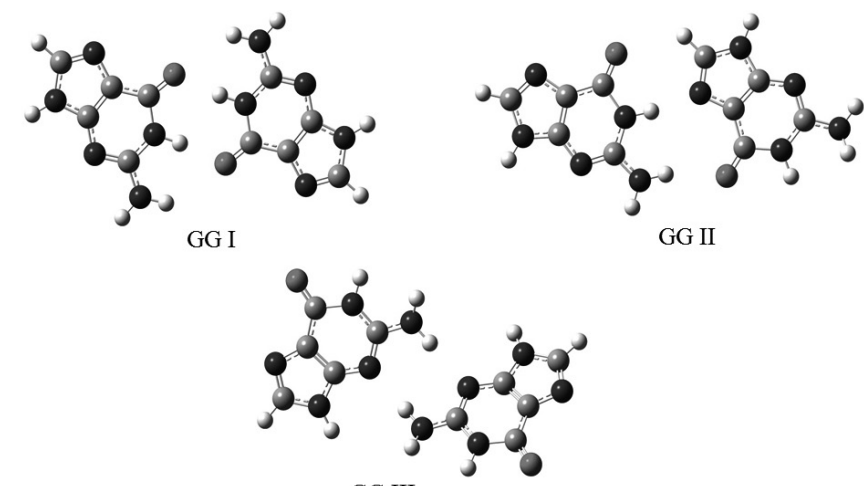

GG III

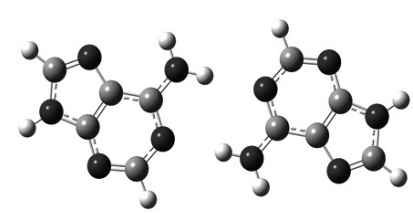

AA I

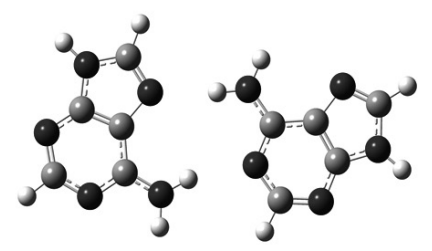

AA II
Fig. 2: Optimized structures of the GG and AA pairs at the level HF/6$31 \mathrm{G}(\mathrm{d}, \mathrm{p})$ level.

Table 1: Bond distances $(\AA)$ and angles (degrees) for GG and AA pairs in gas phase at HF/6-31G(d,p) level.

\begin{tabular}{|c|c|c|c|c|c|}
\hline $\begin{array}{l}\text { Base } \\
\text { Pairs }\end{array}$ & $\begin{array}{l}\text { Hydrogen } \\
\text { bond }\end{array}$ & $\begin{array}{c}\text { Interaction } \\
\text { Edges }\end{array}$ & $\begin{array}{c}\text { Bond } \\
\text { distances } \\
(\AA)\end{array}$ & $\begin{array}{l}\text { Non-bonded } \\
\text { distances } \\
(\AA)\end{array}$ & $\begin{array}{c}\text { Bond angles } \\
\text { (grades) }\end{array}$ \\
\hline GG I & $\begin{array}{l}\mathrm{N}_{1}-\mathrm{H}_{\cdots} \mathrm{O}_{6} \\
\mathrm{O}_{6} \cdots \mathrm{N}_{1}-\mathrm{H}\end{array}$ & WC/WC & $\begin{array}{l}1.87 \\
1.87\end{array}$ & $\begin{array}{l}2.90 \\
2.90\end{array}$ & $\begin{array}{l}174.9 \\
174.9\end{array}$ \\
\hline GG II & $\begin{array}{l}\mathrm{N}_{1}-\mathrm{H}^{\cdots \cdots} \mathrm{N}_{7} \\
\mathrm{~N}_{2}-\mathrm{H}^{\cdots} \cdots \mathrm{O}_{6}\end{array}$ & $\mathrm{WC} / \mathrm{H}$ & $\begin{array}{l}1.96 \\
2.30\end{array}$ & $\begin{array}{l}2.96 \\
3.28\end{array}$ & $\begin{array}{l}172.4 \\
166.0\end{array}$ \\
\hline GG III & $\begin{array}{l}\mathrm{N}_{2}-\mathrm{H} \cdots \mathrm{N}_{3} \\
\mathrm{~N}_{3} \cdots \mathrm{H}-\mathrm{N}_{2}\end{array}$ & $\mathrm{~S} / \mathrm{S}$ & $\begin{array}{l}2.15 \\
2.15\end{array}$ & $\begin{array}{l}3.15 \\
3.15\end{array}$ & $\begin{array}{l}175.7 \\
175.7\end{array}$ \\
\hline AA I & $\begin{array}{l}\mathrm{N}_{6}-\mathrm{H} \cdots \mathrm{N}_{1} \\
\mathrm{~N}_{1} \cdots \mathrm{N}_{6}-\mathrm{H}\end{array}$ & $\mathrm{WC} / \mathrm{WC}$ & $\begin{array}{l}2.16 \\
2.16\end{array}$ & $\begin{array}{l}3.16 \\
3.16\end{array}$ & $\begin{array}{l}179.4 \\
179.4\end{array}$ \\
\hline AA II & $\begin{array}{l}\mathrm{N}_{7}-\mathrm{H} \cdots \mathrm{N}_{6} \\
\mathrm{~N}_{6}-\mathrm{H} \cdots \mathrm{N}_{1}\end{array}$ & $\mathrm{WC} / \mathrm{H}$ & $\begin{array}{l}2.16 \\
2.20\end{array}$ & $\begin{array}{l}3.16 \\
3.18\end{array}$ & $\begin{array}{l}174.9 \\
163.7\end{array}$ \\
\hline
\end{tabular}

X-ray diffraction study ${ }^{38}$ reveals that in the solid state as well in the monohydrate of the pair formed by two molecules of 9-ethyl-guanine, the bond distance $\mathrm{N}_{2}-\mathrm{H}^{\cdots} \mathrm{O}_{6}$, is larger than $\mathrm{N}_{7} \cdots \mathrm{N}_{1}-\mathrm{H}$, in good agreement to our results (Table 1), a difference of $0.34 \AA$ in the GG II pair has been determined. The bond distances $\mathrm{N}_{1}-\mathrm{H} \cdots \mathrm{O}_{6}$ in the par CG I pair deviates ca. $0.13 \AA$ with respect to the ab-initio geometry of the dimer formed by two molecules of 9-methylguanine $^{39}$. It is observed the interactions between nucleobases that involve primary amino group; id. N2 of Guanine or N6 of Adenine, tend to adopt a significant deviation from the plane due to pyramidalization of the $-\mathrm{NH}_{2}$ group, these results are agree with previous studies ${ }^{11}$.

Although the intervention of $\mathrm{N} 1$ of Guanine determines the planarity of the amino group, this is only coincident with our results in GG I pair but not in AA I pair, where the latter one it is showing a structure completely planar although N6 in both purine is forming hydrogen bonds. Interaction in $\mathrm{S} / \mathrm{S}$ GG pair determines a large deviation from both heterocycles from the plane and the pyramidalization of both amino groups involved in the formation of hydrogen bonds. The effect of the solvent does not affect significantly the geometric parameters of the pairs studied. However, it determines the loss of the pyramidalization of both amino groups and the co-planarity of the heterocycles in GG III pair. The latter one together AA I pair form part of the three-dimensional structure of the $\mathrm{RNA}^{26}$, where they interact with $\mathrm{GC}$ and $\mathrm{AU}$ pairs in the formation of bases triples, modifying the conformational properties of those ones.
The non-planarity of the nitrogen bases exo-cyclic amino group plays an important role in the biological processes ${ }^{40}$, favoring the formation of hydrogen bonds ${ }^{41}$, however, theoretical and experimental results ${ }^{39}$, show a favorable inclusion of a water molecule between the $-\mathrm{NH}_{2}$ group and the $\mathrm{O} 6$ of the two purine in GG I pair, where the $-\mathrm{NH}_{2}$ group are not occupied in the formation of the hydrogen bonds $\mathrm{N}_{1}-\mathrm{H} . . . \mathrm{O} 6$, is fully planar as in AA I and AA II pairs, while $\mathrm{WC} / \mathrm{H}$ GG interactions, the amino group remains pyramidal as in isolated Guanine. Both GG II and AA II pairs have been observed in triplex structures formed by DNA and a third strand of oligonucleotide (DNA or RNA), where groups $-\mathrm{NH}_{2}$ of both Guanines are occupied in the formation of hydrogen bonds and the 06 of Guanine and N7 of Adenine are located towards the minor and major groove respectively ${ }^{24,25}$, allowing the inclusion of divalent metal ions ${ }^{3}$. The inclusion of antiviral drugs and antibiotics is produced in areas of DNA with high concentrations of AT base pair, where the $-\mathrm{NH}_{2}$ group is absent; in fact neomycin stabilizes DNA triplex structure with TAT bases triples ${ }^{3,5,25}$.

The calculated interaction energies (Table 2) at the HF/6-31G (d,p) level, show that stability follows the order: $\mathrm{WC} / \mathrm{WC}>\mathrm{WC} / \mathrm{H}>\mathrm{S} / \mathrm{S}$ and their values are in the range of the ab-initio energy $(-5 \mathrm{y}-27 \mathrm{kcal} / \mathrm{mol})$ for RNA base pairs ${ }^{11,42}$. The different energetic stabilities of some interactions allow understanding the functional and structural role of DNA and RNA. 
Table 2: Interaction and solvation energy of the base pairs (Kcal/mol).

\begin{tabular}{|c|c|c|c|c|c|}
\hline \multirow{2}{*}{$\begin{array}{l}\text { Base } \\
\text { Pairs }\end{array}$} & \multirow{2}{*}{$\begin{array}{l}\text { Hydrogen } \\
\text { bond }\end{array}$} & \multicolumn{3}{|c|}{$\begin{array}{l}\text { Interaction energy in gas phase }\left(\mathrm{E}_{\text {gas }}\right) \\
\mathrm{Kcal} / \mathrm{mol}\end{array}$} & \multirow{2}{*}{$\begin{array}{c}\begin{array}{l}\text { Solvation energy }\left(\mathrm{E}_{\text {solv }} .\right. \\
\mathrm{Kcal} / \mathrm{mol}\end{array} \\
\mathrm{HF} \\
6-31 \mathrm{G}(\mathrm{d}, \mathrm{p})\end{array}$} \\
\hline & & $\underset{6-31 G(d, p)}{H F}$ & $\begin{array}{c}\text { MP2 } \\
\text { 6-31G(d,p) }\end{array}$ & $\begin{array}{c}\text { MP2 } \\
\text { 6-311G(d,p) }\end{array}$ & \\
\hline GG I & $\begin{array}{l}\mathrm{N}_{1}-\mathrm{H} \cdots \mathrm{O}_{6} \\
\mathrm{O}_{6} \cdots \mathrm{N}_{1}-\mathrm{H}\end{array}$ & -21.9 & -24.2 & -20.0 & -20.6 \\
\hline GG II & $\begin{array}{l}\mathrm{N}_{1}-\mathrm{H} \cdots \mathrm{N}_{7} \\
\mathrm{~N}_{2}-\mathrm{H} \cdots \mathrm{O}_{6}\end{array}$ & -14.6 & -14.5 & -16.5 & -26.2 \\
\hline GG III & $\begin{array}{l}\mathrm{N}_{2}-\mathrm{H} \cdots \mathrm{N}_{3} \\
\mathrm{~N}_{3} \cdots \mathrm{H}-\mathrm{N}_{2}\end{array}$ & -6.6 & -8.9 & -9.8 & -32.9 \\
\hline AA I & $\begin{array}{l}\mathrm{N}_{6}-\mathrm{H} \cdots \mathrm{N}_{1} \\
\mathrm{~N}_{1} \cdots \mathrm{N}_{6}-\mathrm{H}\end{array}$ & -8.20 & -11.4 & -11.1 & -15.3 \\
\hline AA II & $\begin{array}{l}\mathrm{N}_{7}-\mathrm{H} \cdots \mathrm{N}_{6} \\
\mathrm{~N}_{6}-\mathrm{H}^{\cdots} \mathrm{N}_{1}\end{array}$ & -7.1 & -10.1 & -10.0 & -16.0 \\
\hline
\end{tabular}

a: $\mathrm{E}_{\text {solv. }}=\mathrm{E}_{\text {pair (aqueous solution) }}-\mathrm{E}_{\text {pair (gas phase) }}$

The corrected energies (Table 2), show that the interactions WC/WC are energetically favorable, however, GG I pair is ca. $13.7 \mathrm{kcal} / \mathrm{mol}$ more stable than AA I pair. The hydrogen bonds formed by the Hoogsteen and WatsonCrick sides of both Guanines in GG II pair are ca. $8.0 \mathrm{kcal} / \mathrm{mol}$ less stable that in $\mathrm{WC} / \mathrm{WC}$ in $\mathrm{GC}$ pair $^{35}$ but $4.8 \mathrm{kcal} / \mathrm{mol}$ more stable that the calculated for $\mathrm{AU}$, where the latter one is ca. $5.0 \mathrm{kcal} / \mathrm{mol}$ more stable than the bonding $\mathrm{WC} / \mathrm{H}$ in AA. The different energetic stability between $\mathrm{GC}$ and $\mathrm{AU}$ pairs is ca. $11.0 \mathrm{kcal} / \mathrm{mol}$ at $\mathrm{HF} / 6-31 \mathrm{G}(\mathrm{d}, \mathrm{p})$ level ${ }^{35-36}$. These results could explain the thermodynamic stability differences of some RNA internal loops ${ }^{15}$ that vary between -1.3 and $+3.4 \mathrm{kcal} / \mathrm{mol}$ and whose three-dimensional structure is determined by interactions $\mathrm{WC} / \mathrm{H} \mathrm{GG}$ and $\mathrm{WC} / \mathrm{H}$ AA pairs, in addition to $\mathrm{WC} /$ WC GC and AU pairs. Hydrogen bond from interaction WC/H in GG pair, are better solvated in aqueous solution that interactions WC/WC in GC pair ${ }^{36}$.In fact, a difference ca. $1.8 \mathrm{kcal} / \mathrm{mol}$ is observed.

According to the results obtained, there is not a clear relationship between energetic stability of the different interaction models and the functional role that exerted within the oligonucleotide, observing that the orientation of glycosidic bonds relative to hydrogen bonds also plays an important role. In fact, while cis WC/H GG pair form quartets of Guanines, the orientation trans promotes the formation of DNA triplex structures. However, the difference in energy between both types of interactions between Guanines is $<7 \mathrm{kcal} / \mathrm{mol}$, being more favorable the trans GG interaction ${ }^{11,37,42}$.

\section{CONCLUSIONS}

The nucleobases of DNA and RNA are able to form hydrogen bonding using all electron donor and acceptor groups and the intrinsic stability, geometrical properties in addition to the other properties, allow understanding the functional role of the nucleobases in the molecular recognition processes. According to the obtained results, the Watson-Crick interactions between nucleobases of the same type are more favorable than Watson-Crick/Hoogsteen and Sugar/Sugar interactions. Though, $\mathrm{WC} / \mathrm{WC}$ and $\mathrm{WC} / \mathrm{H}$ interactions, between two Guanines are energetically more favorable than those formed by two Adenines.

\section{ACKNOWLEDGEMENTS}

This work was supported by operating grants (S-2010-07) from the Universidad Austral de Chile and $\mathrm{N}^{\circ} 208.021 .027-1$ from the Universidad de Concepcion, Chile

\section{REFERENCES}

1.- $\quad$ G. Werstuck, ML. Zapp, MR. Green, Chem. Biol. 3, 129 (1996)

2.- T. Hermann, E. Westhof, Chem. Biol. 6, R335 (1999).

3.- $\quad$ MJ. Hannon, Chem. Soc. Rev. 36, 280 (2007).

4.- T. Tran, MD. Disney, Biochemistry. 49, 1833, (2010).

5.- DP. Arya, Acc.Chem. Res. 44, 134 (2011).
6.- JA. Cruz, E. Westhof, Nature Methods. 8, 513 (2011).

7.- J. Kondo, E. Westhof, J. Mol. Recognit. 23, 241 (2010).

8.- $\quad$ SM Haider, S. Neidle, GN Parkinson, Biochimie. 93, 1239 (2011).

9.- NB. Leontis, J. Stombaugh, E. Westhof, Nucleic Acids Res. 30, 3497 (2002).

10.- J. Kondo, E. Westhof, Nucleic Acids Res. 39, 8628 (2011).

11.- A. Roy, S. Panigrahi, M. Bhattacharyya, D. Bhattacharyya, J. Phys. Chem. B112, 3786 (2008).

12.- SD. McCulloch, TA. Kunkel, Cell Res. 18, 148 (2008).

13.- SE. Butcher, AM. Pyle, Accounts of Chemical Research. 44, 1302 (2011).

14.- E. Westhof, B. Masquida, F. Jossinet, Cold. Spring. Harb. Perspect. Biol. 3:a003632 (2011).

15.- NB. Hammond, BS. Tolbert, R. Kierzek, DH. Turner, SD. Kennedy, Biochemistry. 49, 5817 (2010).

16.- D. Bhattacharyya, S. Ramachandran, S. Sharma, W. Pathmasiri, C. King, I. Baskerville, G. Bysen, J. Swenberg, S. Campbell, N. Dokhlyan, S. Chaney. PLoS ONE. 6, e23582 (2011).

17.- S. Pérez-Yañez, O. Castillo, J. Cepeda, J. García-Terán, A. Luque, P. Román, Inorgánica Chimica Acta. 365, 211 (2011).

18.- Y. Wu, RM. Brosh Jr., FEBS Journal. 277, 3470 (2010).

19.- DL. Ma, DS. Chan, P. Lee, MH. Kwan, CH. Leung, Biochimie. 93, 1252 (2011).

20.- T. Hermann, E. Westhof, Biopolymers (Nucleic Acid Sciences). 48, 155 (1998).

21.- MD. Disney, LP. Labuda, DJ. Paul, SG. Poplawski, A. Pushechnikov, T. Tran, SP. Velagapudi, M. Wu, JL. Childs-Disney. J. Am. Chem. Soc. 130, 11185 (2008).

22.- AP. Carter, WM. Clemons, DV. Brodersen, RJ. Morgan-Warren, BT. Wimberly, V. Ramakrishnan. Nature, 407, 340 (2000).

23.- FA. Buske, JS. Mattick, TL. Bailey, RNA Biology. 8, 427 (2011).

24.- A. Jain, G. Wang, KM. Vasquez, Biochimie. 90, 1117 (2008).

25.- DP. Arya. Accounts of Chemical Research. 44, 134 (2011).

26.- S. Mukherjee, M. Bansal, D. Bhattacharyya, J. Comput. Aided Mol. Des. 20, 629 (2006).

27.- P. Sharma, A. Mitra, S. Sharma, H. Singh, D. Bhattacharyya, J. Biomol. Struct. Dyn. 25, 709 (2008).

28.- MJ. Frisch, GW. Trucks, HB. Schlegel, GE. Scuseria, MA. Robb, JR. Cheeseman, G. Scalmani, V. Barone, B. Mennucci, GA. Petersson, H. Nakatsuji, M. Caricato, X. Li, HP. Hratchian, AF. Izmaylov, J. Bloino, G. Zheng, JL. Sonnenberg, M. Hada, M. Ehara, K. Toyota, R. Fukuda, J. Hasegawa, M. Ishida, T. Nakajima, Y. Honda, O. Kitao, H. Nakai, T. Vreven, JA. Montgomery, Jr., JE. Peralta, F. Ogliaro, M. Bearpark, JJ. Heyd, E. Brothers, KN. Kudin, VN. Staroverov, T. Keith, R. Kobayashi, J. Normand, K. Raghavachari, A. Rendell, JC. Burant, S. S. Iyengar, J. Tomasi, M. Cossi, N. Rega, J. M. Millam, M. Klene, JE. Knox, JB. Cross, V. Bakken, C. Adamo, J. Jaramillo, R. Gomperts, RE. Stratmann, O. Yazyev, AJ. Austin, R. Cammi, C. Pomelli, JW. Ochterski, RL. Martin, 
K. Morokuma, VG. Zakrzewski, GA. Voth, P. Salvador, JJ. Dannenberg, S. Dapprich, AD. Daniels, O. Farkas, JB. Foresman, JV. Ortiz, J. Cioslowski, and DJ. Fox, Gaussian, Inc., Wallingford CT, 2010.

29.- SF. Boys, F. Bernardi, Mol. Phys. 19, 553 (1970).

30.- P. Hobza, R. Zahradnik, Chem. Rev. 88, 871 (1988).

31.- DW. Schewenke, DG. Truhlar, J. Chem. Phys. 82, 2418 (1985).

32.- J. Tomasi, M. Persico, Chem. Rev. 94, 2027 (1994).

33.- MT Cances, V. Mennucci, J. Tomasi, J. Chem. Phys. 107, 3032 (1997).

34.- J. Sponer, J. Leszczynski, P. Hobza, Biopolymers (Nucleic Acid Sciences). 61, 3 (2002).

35.- JG. Contreras, ST. Madariaga, Biorg. Chem. 31, 367 (2003).
36.- ST. Madariaga, JG. Contreras, CG. Seguel, J. Chil. Chem. Soc. 50, 435 (2005).

37.- ST. Madariaga, JG. Contreras. J. Chil. Chem. Soc. 55, 50 (2010).

38.- P. Amo-Ochoa, PJ. Sanz Miguel, O. Castillo, M. Sabat, B. Lippert, F. Zamora, J. Biol. Inorg. Chem. 12, 543 (2007).

39.- S. Urashima, H. Asami, M. Ohba, H. Saigusa, J. Phys. Chem. A. 114 $11231(2010)$.

40.- G. Varani, WH. McClain, EMBo reports. 1, 18 (2000).

41.- K. Sen, S. Basu, D. Bhattacharyya, Int. J. Quant. Chem. 106, 913 (2006).

42.- D. Bhattacharyya, SC. Koripella, A. Mitra, VB. Rajendran, B. Sinha, J. Biosci. 32, 809 (2007) 